\title{
GROWTH OF Manilkara huberi AND Manilkara paraensis AFTER LOGGING AND SILVICULTURAL TREATMENTS IN THE MUNICIPALITY OF PARAGOMINAS, PARÁ, BRAZIL
}

\author{
Deivison Venicio Souza ${ }^{1}$, João Olegário Pereira de Carvalho $^{2}$, Fernanda da Silva Mendes ${ }^{3}$, Lia de \\ Oliveira Melo ${ }^{4}$, José Natalino Macedo Silva ${ }^{5}$, Fernando Cristóvam da Silva Jardim ${ }^{6}$ \\ ${ }^{1}$ Forest Engineer, M.Sc., UFPA, Altamira, PA, Brazil - deivisonvs@ufpa.br \\ ${ }^{2}$ Forest Engineer, Ph.D., UFRA/CAPES/CNPq, Ananindeua, PA, Brazil - olegario@pq.cnpq.br \\ ${ }^{3}$ Forest Engineer, M.Sc., UEPA, Belém, PA, Brazil - mendes.fsm@ gmail.com \\ ${ }^{4}$ Forest Engineer, Dr., UFOPA, Santarém, PA, Brazil - lcolivei@gmail.com \\ ${ }^{5}$ Forest Engineer, Ph.D., UFRA, Belém, PA, Brazil - silvanatalino734@gmail.com \\ ${ }^{6}$ Forest Engineer, Dr., UFRA, Belém, PA, Brazil - fernando.jardim@ufra.edu.br \\ Received for publication 05/07/2012 - Accepted for publication 03/03/2014
}

\begin{abstract}
The effects of silvicultural treatments and logging on the growth rates of Manilkara huberi and Manilkara paraensis in a terra firme natural forest were evaluated. The study was performed in a Forest Management Unit (FMU) located in the municipality of Paragominas, PA. The experimental area covered 500 ha, where five treatments (100 ha each), with four replications per treatment ( 25 ha each), were established. The replications were randomly distributed in the 500 ha sample area of the FMU. The growth rate of trees was evaluated in the following treatments: T1 - Reduced Impact Logging (RIL) + classic liberation thinning and climber cutting; T2 - RIL + modified liberation thinning and climber cutting; T3 - RIL + climber cutting; T6 - only RIL; T7 - unlogged forest (control). Manilkara huberi and Manilkara paraensis showed good responses on diameter growth rate to the post-harvesting silvicultural treatments applied. However, considering the growth rate differences between the evaluated periods, one can say that the short time elapsed from the application of silvicultural treatments (four years) to the end of the study period does not allow to make accurate statements about the most appropriate treatment for the species, or about the intensity of the interventions to be applied.

Keywords: Diameter increment; post-harvesting silviculture; tree girdling; climber cutting.
\end{abstract}

\section{Resumo}

Crescimento de Manilkara huberi e Manilkara paraensis após a colheita de madeira e tratamentos silviculturais, paragominas, Pará, Brasil. Foram avaliados os efeitos de tratamentos silviculturais e da colheita de madeira sobre o crescimento diamétrico das espécies Manilkara huberi e Manilkara paraensis em uma floresta natural de terra firme. A pesquisa foi conduzida em uma Unidade de Manejo Florestal (UMF), município de Paragominas, PA. A área experimental correspondeu a 500 ha, onde foram estabelecidos cinco tratamentos (100 ha cada) com quatro repetições ( 25 ha cada). As repetições foram distribuídas aleatoriamente na amostra de 500 ha na UMF. O crescimento das árvores foi avaliado nos seguintes tratamentos: T1 - exploração de impacto reduzido (EIR) + desbaste de liberação clássico e corte de cipós; T2 - EIR + desbaste de liberação modificado e corte de cipós; T3 - EIR + corte de cipós; T6 - apenas EIR; T7 - floresta não-explorada. Manilkara huberi e Manilkara paraensis mostraram respostas favoráveis, em termos de crescimento em diâmetro, às intervenções silviculturais pósexploratórias aplicadas. Contudo, considerando as diferenças no incremento das árvores entre os períodos avaliados, pode-se dizer que o curto espaço de tempo decorrido da aplicação dos tratamentos silviculturais (quatro anos) ainda não permite fazer projeções precisas acerca do tratamento mais adequado às espécies, ou mesmo, da intensidade das intervenções a serem aplicadas.

Palavras-chave: Incremento diamétrico; silvicultura pós-colheita; anelagem de árvores, corte de cipós.

\section{INTRODUCTION}

The silvicultural systems in the field of sustainable forest management were defined starting from the necessity to overcome intrinsic problems of the tropical forests, that is to say scarceness of natural regeneration and diminished growth rate of valuable species. In terms of silvicultural practices, the great challenge of the tropical forests management is to find a silvicultural model granting enough 
natural regeneration and growth rates increase of desirable tree species, paying attention, among other aspects, to the excessive regeneration of undesirable and invading species which could impair the sustainability of timber production.

To describe how important is the knowledge of the tree growth rates for the forest management it is enough to say that, according to Silva et al. (2001), until the beginning of 1980 there was practically no information about the natural forests growth in the Brazilian Amazon region. However, starting from 1981, Embrapa Amazônia Oriental started to establish a network of permanent plots with the intent to gather information on growth rates of the terra firme (dry land) forests of the region.

The understanding of the mechanisms and dynamics involved into growth and development of the tree species may help to answer many of the emerging questions when productivity and conservation have to coexist (SILVA et al., 2003). In the specific case of the forest management oriented to timber production, this understanding is fundamental for important decision makings like: i) choice of the species that can be logged; ii) choice of the species that must be protected; iii) more accurate prevision of the cutting cycle; and iv) prescription of silvicultural treatments.

Studies that were conducted in the tropical forests have revealed that silvicultural treatments performed after logging may significantly increase the growth rates (WADSWORTH; ZWEEDE, 2006; PEÑA-CLAROS et al., 2008; VILLEGAS et al., 2009). Silva (2001) affirms that the growth rate of individuals that received silvicultural treatments may double compared to the logged and not consequently treated forest areas, or even quadruplicate compared to the unlogged forest. For this reason, knowledge of the forest population growth rates, or just of the economically interesting forest species, after the application of silvicultural treatments following the planned forest harvesting, is fundamental to achieve sustainability of the forest timber production. However, information on natural forests silviculture are still scarce, hence the necessity of studies to subsidize the prescription of adequate treatments.

The objective of this study was to evaluate the diameter growth rate of Manilkara huberi (Ducke) Chevalier and Manilkara paraensis (Huber) Standl. after logging and application of silvicultural treatments in a terra firme forest, with the purpose of generating information which could contribute to the management of the two species within systems used in the natural forests of the Amazon region.

\section{MATERIALS AND METHODS}

\section{Characteristics of the studied area}

This study was carried out in the Fazenda Rio Capim Forest Management Unit (FMU), belonging to Cikel Brasil Verde Madeiras Ltda, located between the geographical coordinates $03^{\circ} 30^{\prime}$ and $03^{\circ} 45^{\prime}$ latitude South and $48^{\circ} 30^{\prime}$ and $48^{\circ} 45^{\prime}$ longitude West, in the municipality of Paragominas, Pará (MACIEL et al., 2009).

The predominant climate in the region is "Aw", according to the Köppen classification, that is to say tropical rainy with defined dry season, characterized by average temperature of $27.2^{\circ} \mathrm{C}$, with average relative humidity equal to $81 \%$ and $1766 \mathrm{~mm}$ of rainfall per year, with possible diminished water availability in the period from July to October (WATRIN; ROCHA, 1992).

The most common soils in the municipality of Paragominas are: Yellow Latosols; Yellow Ultisols; Plinthosol; Gleysols and Neosols (RODRIGUES et al., 2003). According to Veloso et al. (1991), the forest type of the region is classified as dense ombrophylous forest.

\section{Experimental design}

Seven treatments were established in the experimental area, distributed in 6 WUs (Working Units) in the APU 7 (Annual Production Unit $\mathrm{n}^{\circ}$ 7) and 8 WUs in APU 8, in the Fazenda Rio Capim FMU, comprising a total sample area of 700ha, from whici 600ha were logged using reduced impact logging techniques (RIL).

The growth rates of Manilkara huberi and Manilkara paraensis were assessed for five treatments (T1, T2, T3, T6 and T7) for a total of 500 hectares. The experimental design was completely randomized. Each treatment had four replications. Each WU was divided into four 25 ha square plots, which represented the replications, and where the silvicultural treatments were conducted. Each replication of 25 ha had a border strip of 4.75 ha ( $25 \mathrm{~m}$ on each side). The effective area of the replication center was then $20.25 \mathrm{ha}(450 \mathrm{~m}$ x $450 \mathrm{~m})$. Resuming, each treatment was as follows: 
T1 RIL + Classic thinning (WADSWORTH, 2000) by girdling, and climber cutting in trees selected for future harvestings (Potential Crop Trees - PCT), which are the trees of species whose timber is currently commercialized. This was the most rigorous treatment, because besides girdling of the competitor trees which were overtopping the PCTs, girdling was applied also in trees found less than $2 \mathrm{~m}$ from the PCT; a distance table depending on the diameter of the PCTs and of their competitors was used to decide if girdling could be applied. The table is based on the concept of minimum distance between the PCT and the competitor tree, that is to say that the minimum distance between PCT and competitor trees, for which competition is considered not existing, is calculated basing on the sum of DBH (diameters measured at 1.30 meters above the ground) of PCTs and competitors.

T2 RIL + modified thinning (a variation of the classic), by girdling and climber cutting of the PCT, which similarly to $\mathrm{T} 1$, also were trees of species whose timber is currently commercialized. It was called Modified because there was no girdling of trees found at two meters of distance from the PCTs, neither the distance table based on diameters was used;

T3 RIL + Climber cutting on the PCTs, which in this treatment were trees of any species, independently on their timber being commercialized or not;

T4 RIL + Planting in logging gaps, conservation of some seedlings from natural regeneration of commercially valuable species found in the logging gaps, climber cutting on PCTs;

T5 Formed by the activities of T2 plus the activities of T4;

T6 Just RIL. In this treatment there was only harvesting of trees from commercial species according to the Cikel Forest Management Plan;

T7 Unlogged forest.

The minimum DBH (diameter at $1.30 \mathrm{~m}$ above ground) used to select trees of Manilkara huberi and Manilkara paraensis. to be benefited by the silvicultural treatments was $35 \mathrm{~cm}$. The trees, to be chosen, had also to be healthy and straightly shaped.

The girdling type applied in the treatments was complete, which, according to Sandel and Carvalho (2000), consists in extracting the bark and cambium of the tree, with an hatchet, forming a complete ring about $30 \mathrm{~cm}$ wide, approximately at $1 \mathrm{~m}$ above the ground. This activity was performed with machete and/or hatchet.

\section{Data collection and analysis}

Data were collected in four occasions, in the years 2005, 2006, 2007 and 2009. DBH was measured in all the PCTs (DBH equal or greater than $35 \mathrm{~cm}$ ). Shape and illumination on the tree crown and presence and effect of climbers in the trees were assessed, according to Silva et al. (2005).

The parameter used to assess the diameter growth of the PCTs was the PAI $\mathrm{DBH}_{\text {(Periodic Annual }}$ Increment of the $\mathrm{DBH})$, calculated by using the equation $\mathrm{PAI}_{\mathrm{DBH}}=\left(\mathrm{DBH}_{\text {final }}-\mathrm{DBH}_{\text {initial }}\right) / \mathrm{t}$, where: $\mathrm{DBH}_{\text {fina }}$ is the $\mathrm{DBH}$ obtained at the end of the measuring interval; $\mathrm{DBH}_{\text {initial }}$ is the $\mathrm{DBH}$ obtained at the beginning of the measuring interval; and $t$ is the time interval, in years, between two measurements. Four periods were assessed: I (from 2005 to 2006); II (from 2006 to 2007); III (from 2007 to 2009) and IV (from 2005 to 2009).

Tests of the Kolmogorov-Smirnov and Levene hypotheses were performed to respectively evaluate suppositions of normality and homoscedasticity of the variances required by the parametric tests. The tests reported uneven variances and revealed that the distribution of sample data does not follow a normal distribution curve. Since the assumptions of the Analysis of Variance (ANOVA) were not satisfied, the non-parametric Kruskal-Wallis test (test $\mathrm{H}$ ) was used with the intent to compare the diametric growth between the experimental treatments, in all the assessment periods considered.

To evaluate the growth rates of the trees, in relation to the silvicultural variables (level of exposition to solar radiation on the tree crowns, presence and effect of climbers), only the individuals which maintained the same silvicultural conditions in consecutive measurements were considered. For the analysis of the entire evaluation period (2005 to 2009), were considered only individuals which maintained the same silvicultural conditions in all the four measurement performed.

To compare the DBH growth rates in relation to the silvicultural variables, the tests of KruskalWallis ( $\mathrm{K}$ independent samples - $\mathrm{K}>2$ ) or Mann-Whitney (two independent samples - $\mathrm{K}=2$ ) were applied. The post hoc test of multiple comparison, Dunn test, was performed only when the null hypothesis established for the test of Kruskal-Wallis was rejected. 


\section{RESULTS AND DISCUSSION}

\section{Growth in diameter}

The periodic annual increment of Manilkara huberi and Manilkara paraensis trees with DBH greater than or equal to $35 \mathrm{~cm}$, in the five experimental treatments and in the four assessed periods, is presented respectively in tables 1 and 2 .

Table 1. Periodic annual DBH increment $\left(\mathrm{cm}^{-1}{ }^{-1}\right)$ of Manilkara huberi trees with DBH greater than or equal to $35 \mathrm{~cm}$ in a 500 ha area of terra firme natural forest, in the municipality of Paragominas, PA.

Tabela 1. Incremento periódico anual em DAP $\left(\mathrm{cm} \mathrm{ano}^{-1}\right)$ de árvores de Manilkara huberi com DAP maior ou igual a $35 \mathrm{~cm}$, em 500 ha de uma floresta natural de terra firme, Paragominas, PA.

\begin{tabular}{|c|c|c|c|c|c|c|c|c|c|}
\hline \multirow{2}{*}{ Treatments } & \multirow{2}{*}{$\mathbf{n}$} & \multicolumn{2}{|c|}{$2005-2006$} & \multicolumn{2}{|c|}{ 2006-2007 } & \multicolumn{2}{|c|}{ 2007-2009 } & \multicolumn{2}{|c|}{ 2005-2009 } \\
\hline & & $\mathbf{P A I}_{\text {DBH }}$ & Sd & PAI $_{\text {DBH }}$ & Sd & $\mathbf{P A I}_{\text {DBH }}$ & Sd & $\mathbf{P A I}_{\text {DBH }}$ & Sd \\
\hline $\mathrm{T} 1$ & 35 & 0.64 & 0.47 & 0.44 & 0.28 & $0.74 \mathrm{ab}$ & 0.27 & $0.58 \mathrm{a}$ & 0.24 \\
\hline $\mathrm{T} 2$ & 39 & 0.50 & 0.38 & 0.38 & 0.31 & $0.64 \mathrm{ab}$ & 0.32 & $0.50 \mathrm{ab}$ & 0.27 \\
\hline $\mathrm{T} 3$ & 38 & 0.59 & 0.44 & 0.43 & 0.30 & $0.80 \mathrm{a}$ & 0.38 & $0.59 \mathrm{a}$ & 0.27 \\
\hline T6 & 28 & 0.59 & 0.49 & 0.41 & 0.26 & $0.56 \mathrm{bc}$ & 0.38 & $0.49 a b$ & 0.27 \\
\hline $\mathrm{T} 7$ & 137 & 0.46 & 0.46 & 0.39 & 0.31 & $0.41 \mathrm{c}$ & 0.34 & $0.41 \mathrm{~b}$ & 0.24 \\
\hline $\mathrm{H}$ & - & \multicolumn{2}{|c|}{7.5442} & \multicolumn{2}{|c|}{1,7860} & \multicolumn{2}{|c|}{52,5787} & \multicolumn{2}{|c|}{22,6647} \\
\hline$P$-value & - & \multicolumn{2}{|c|}{0.1098} & \multicolumn{2}{|c|}{0.7750} & \multicolumn{2}{|c|}{0.000} & \multicolumn{2}{|c|}{0.000} \\
\hline
\end{tabular}

T1: Reduced Impact Logging (RIL) + classic thinning and climber cutting; T2: RIL + modified thinning and climber cutting; T3: RIL + climber cutting; T6: just RIL; T7: Unlogged forest. n: number of individuals. Sd: Standard deviation. H: statistic value of Kruskal-Wallis. P-value: indicated the level of significance of the Kruskal-Wallis test for each period of assessment $(\alpha=0.05)$. Treatments with different letters, per each assessment period, are significantly different according with the post-hoc test of Dunn for multiple comparisons $(\alpha=0.05)$.

Table 2. Periodic annual DBH increment $\left(\mathrm{cm} \mathrm{year}^{-1}\right)$ of Manilkara paraensis trees with DBH greater than or equal to $35 \mathrm{~cm}$ in a 500 ha area of terra firme natural forest, Paragominas, PA.

Tabela 2. Incremento periódico anual em DAP $\left(\mathrm{cm} \mathrm{ano}^{-1}\right)$ de árvores de Manilkara paraensis com DAP maior ou igual a $35 \mathrm{~cm}$, em 500 ha de uma floresta natural de terra firme, Paragominas, PA.

\begin{tabular}{|c|c|c|c|c|c|c|c|c|c|}
\hline \multirow{2}{*}{ Treatments } & \multirow{2}{*}{$\mathbf{n}$} & \multicolumn{2}{|c|}{$2005-2006$} & \multicolumn{2}{|c|}{ 2006-2007 } & \multicolumn{2}{|c|}{ 2007-2009 } & \multicolumn{2}{|c|}{$2005-2009$} \\
\hline & & $\mathbf{P A I}_{\text {DBH }}$ & Sd & $\mathbf{P A I}_{\text {DBH }}$ & Sd & $\mathbf{P A I}_{\text {DBH }}$ & Sd & $\mathbf{P A I}_{\text {DBH }}$ & Sd \\
\hline $\mathrm{T} 1$ & 23 & 0.38 & 0.32 & 0.39 & 0.31 & $0.62 \mathrm{ab}$ & 0.21 & $0.46 \mathrm{a}$ & 0.20 \\
\hline $\mathrm{T} 2$ & 29 & 0.38 & 0.30 & 0.34 & 0.30 & $0.59 \mathrm{ab}$ & 0.28 & $0.44 \mathrm{a}$ & 0.23 \\
\hline $\mathrm{T} 3$ & 35 & 0.39 & 0.33 & 0.29 & 0.28 & $0.73 \mathrm{a}$ & 0.32 & $0.46 \mathrm{a}$ & 0.22 \\
\hline T6 & 23 & 0.33 & 0.29 & 0.33 & 0.16 & $0.43 \mathrm{bc}$ & 0.29 & $0.36 \mathrm{ab}$ & 0.17 \\
\hline $\mathrm{T} 7$ & 45 & 0.43 & 0.45 & 0.24 & 0.21 & $0.29 \mathrm{c}$ & 0.27 & $0.29 \mathrm{~b}$ & 0.17 \\
\hline $\mathrm{H}$ & - & \multicolumn{2}{|c|}{0.1630} & \multicolumn{2}{|c|}{3.9162} & \multicolumn{2}{|c|}{41.7943} & \multicolumn{2}{|c|}{17.4589} \\
\hline$P$-value & - & \multicolumn{2}{|c|}{0.9969} & \multicolumn{2}{|c|}{0.4175} & \multicolumn{2}{|c|}{0.000} & \multicolumn{2}{|c|}{0.001} \\
\hline
\end{tabular}

T1: Reduced Impact Logging (RIL) + classic thinning and climber cutting; T2: RIL + modified thinning and climber cutting; T3: RIL + climber cutting; T6: just RIL; T7: Unlogged forest. n: number of individuals. Sd: Standard deviation. H: statistic value of Kruskal-Wallis. P-value: indicated the level of significance of the Kruskal-Wallis test for each period of assessment $(\alpha=0.05)$. Treatments with different letters, by each assessment period, are significantly different according with the post-hoc test of Dunn for multiple comparisons $(\alpha=0.05)$.

In the periods 2005-2006 and 2006-2007, similar rates of periodic annual increment in DBH $\left(\mathrm{PAI}_{\mathrm{DBH}}\right)$ were observed for the species Manilkara huberi and Manilkara paraensis in the five experimental treatments. Results observed in these periods for both species indicate that the short period of time elapsed from the application of the silvicultural treatments after logging (climber cutting and girdling) was not long enough to have a significant increase in the diameter growth. However it is likely that the increment rates observed for T1, T2, T3 and T6 in the period from 2005 to 2006 were more influenced by the opening of the canopy resulted from the Reduced Impact Logging (RIL).

In the period 2006-2007, Manilkara huberi showed reduction in the DBH growth rates when compared to the previous period (2005-2006) in all the experimental treatments. The decreases varied from 24 to $31 \%$ in the treatments were there were interventions in the forest (T1, T2, T3 and T6) and 
approximately 15\% in the unlogged forest (T7). A similar tendency was observed in Manilkara paraensis which revealed decreases of $10.53 \%, 25.64 \%$ and $44.19 \%$, respectively in treatments $\mathrm{T} 2$, T3 and T7. The $\mathrm{T} 1$ treatment showed an increase of $2.63 \%$ and $\mathrm{T} 6$ maintained its $\mathrm{PAI}_{\mathrm{DBH}}$ stable along the two periods.

The decreases in $\mathrm{PAI}_{\mathrm{DBH}}$ rates observed both for Manilkara huberi and Manilkara paraensis, in the period 2006-2007 (three years after logging), are indications of a decrease of the beneficial effects resulting from the canopy opening caused by the timber harvesting, or even are indications of other unknown natural factors taking place. This can be assumed because the reduction in the diameter growth rate was observed also in the unlogged forest.

Significant differences between the experimental treatments were verified only in the periods of 2007-2009 and 2005-2009, for both Manilkara huberi and Manilkara paraensis.

In the period 2007-2009, for both species, the $\mathrm{PAI}_{\mathrm{DBH}}$ rates in $\mathrm{T} 1, \mathrm{~T} 2$ and $\mathrm{T} 3$ treatments were greater than those in the unlogged forest. This fact could be evidence of the more effective contribution, in terms of DBH rates increase, of the post-logging silvicultural interventions. This evidence is supported by the observation that the forest that was simply logged without any further treatment had growth rates similar to the unlogged forest.

There was no significant difference between the combined treatments (T1, T2 and T3) for the two species in the 2007-2009 period. However T3 was the only one that ensured greater growth compared to both the untreated logged forest and the unlogged forest.

In the 2007-2009 period, the PAI $\mathrm{DBH}_{\mathrm{BH}}$ rates in all the experimental treatments showed increases when compared to the previous period (2006-2007), for both species. The average DBH growth of Manilkara huberi increased from 68 to $86 \%$ in the combined treatments. Meanwhile, in the untreated logged forest (T6) and in the unlogged forest (T7), the diameter increment was approximately $36 \%$ and $5 \%$. Manilkara paraensis showed a similar tendency, mainly in T3, where the DBH growth was approximately 2.5 times greater than in the 2006-2007 period.

Considering the entire assessment period (2005-2009), similarly to that occurred in the 20072009 period, Manilkara huberi and Manilkara paraensis showed greater $\mathrm{PAI}_{\mathrm{DBH}}$ in the combined treatments when compared to the unlogged forest (T7). An exception was observed for Manilkara huberi that showed no significant difference between the averages of PAI $\mathrm{DBH}_{\mathrm{DH}}$ in $\mathrm{T} 2$ and $\mathrm{T} 7$ treatments.

In general, the results found for Manilkara huberi and Manilkara paraensis, in the 2007-2009 and 2005-2009 periods, suggest that the two species, even being considered shade-tolerant species (PINHEIRO et al., 2007), they had their growth favored by the post-logging silvicultural activities. But the reduced impact logging, by itself, was not enough to stimulate the DBH growth, mainly when compared to the unlogged forest.

This result contrasts to that reported by Carvalho et al. (2004) that Manilkara huberi had smaller DBH increment in the unlogged forest than in the logged one.

Costa et al. (2007) observed $0.39 \mathrm{~cm}^{\text {year }}{ }^{-1}$ of diameter growth (trees with DBH greater than or equal to $5 \mathrm{~cm}$ ) for Manilkara huberi in an experimental area in the Floresta Nacional do Tapajós. However, the authors reported that the species growth rates varied along time, increasing until the sixth year after logging but decreasing later, fact justified by the decrease of the beneficial effects of the canopy opening on the growth of trees, in other words the competition for space and light increased along time, causing the reduction on growth.

\section{Presence and effect of climbers in the trees}

The Manilkara huberi individuals free of climbers showed DBH growth rates greater than those with climbers, which had growth reduced in the 2007-2009 period. This was also observed for the entire assessment period, when trees free of climbers grew significantly more than the others, however climbers did not cause damages. Manilkara paraensis did not show significant difference on DBH growth, between trees with climbers and trees without climbers, in the four assessed periods (Table 3).

Costa et al. (2007) reported similar results, showing that trees without climbers grew $25 \%$ more than individuals with climbers on the crown. Studies conducted in the Brazilian Amazon region (VIDAL et al., 2002; OLIVEIRA; BRAZ, 2006; COSTA et al., 2008) have reported results similar to these observed for Manilkara huberi, in the two periods, however a group of different species was considered.

Climber cutting showed to be effective, because $72.91 \%$ (T1), $84.62 \%$ (T2) and $65.38 \%$ (T3) of Manilkara huberi trees, and 60\% (T1), 68.75\% (T2) and 48\% (T3) of Manilkara paraensis trees, which were cut, were still free of climbers one year after cutting (Figures 1 and 2). Pérez-Salicrup et al. (2001) found that two years after the application of silvicultural treatment, $78 \%$ of the trees had their crowns free of climbers. 
Table 3. Periodic annual DBH increment $\left(\mathrm{cm} \mathrm{year}^{-1}\right)$ of Manilkara huberi trees and Manilkara paraensis trees with DBH greater than or equal to $35 \mathrm{~cm}$, depending on the presence of climber on the trees selected in a 500 ha sample of a terra firme natural forest, in the municipality of Paragominas, PA.

Tabela 3. Incremento periódico anual em DAP $\left(\mathrm{cm} \mathrm{ano}^{-1}\right)$ das árvores de Manilkara huberi e Manilkara paraensis com DAP maior ou igual a $35 \mathrm{~cm}$, em função da presença de cipós nas árvores selecionadas, em 500 ha de uma floresta natural de terra firme, Paragominas, PA.

\begin{tabular}{|c|c|c|c|c|c|c|c|c|}
\hline Species & Period & $\mathbf{C P}$ & $\mathbf{n}$ & PAI $_{\text {DBH }}$ & Sd & $\mathbf{H}$ & $\mathbf{U}$ & P-value \\
\hline \multirow{12}{*}{$\begin{array}{l}\text { Manilkara } \\
\text { huberi }\end{array}$} & \multirow{3}{*}{$2005-2006$} & I & 64 & 0.57 & 0.41 & \multirow{3}{*}{3.0286} & \multirow{3}{*}{-} & \multirow{3}{*}{0.2200} \\
\hline & & II & 67 & 0.47 & 0.41 & & & \\
\hline & & III & 11 & 0.40 & 0.42 & & & \\
\hline & \multirow{4}{*}{$2006-2007$} & I & 77 & 0.45 & 0.28 & \multirow{4}{*}{3.9277} & \multirow{4}{*}{-} & \multirow{4}{*}{0.2694} \\
\hline & & II & 35 & 0.38 & 0.33 & & & \\
\hline & & III & 9 & 0.32 & 0.27 & & & \\
\hline & & VI & 25 & 0.42 & 0.32 & & & \\
\hline & \multirow{3}{*}{ 2007-2009 } & I & 88 & $0.66 \mathrm{a}$ & 0.38 & \multirow{3}{*}{8.6707} & \multirow{3}{*}{-} & \multirow{3}{*}{0.0131} \\
\hline & & II & 22 & $0.59 \mathrm{ab}$ & 0.45 & & & \\
\hline & & III & 26 & $0.41 \mathrm{~b}$ & 0.29 & & & \\
\hline & \multirow{2}{*}{ 2005-2009 } & I & 46 & 0.57 & 0.24 & \multirow{2}{*}{-} & \multirow{2}{*}{64.50} & \multirow{2}{*}{0.0100} \\
\hline & & II & 7 & 0.31 & 0.22 & & & \\
\hline \multirow{9}{*}{$\begin{array}{l}\text { Manilkara } \\
\text { paraensis }\end{array}$} & \multirow{2}{*}{$2005-2006$} & I & 48 & 0.43 & 0.37 & \multirow{2}{*}{-} & \multirow{2}{*}{703.00} & \multirow{2}{*}{0.8614} \\
\hline & & II & 30 & 0.37 & 0.32 & & & \\
\hline & \multirow{3}{*}{ 2006-2007 } & I & 62 & 0.36 & 0.25 & \multirow{3}{*}{2.4197} & \multirow{3}{*}{-} & \multirow{3}{*}{0.2982} \\
\hline & & II & 17 & 0.29 & 0.21 & & & \\
\hline & & VI & 9 & 0.42 & 0.34 & & & \\
\hline & \multirow{2}{*}{ 2007-2009 } & $\mathrm{I}$ & 66 & 0.58 & 0.33 & \multirow{2}{*}{-} & \multirow{2}{*}{279.50} & \multirow{2}{*}{0.2242} \\
\hline & & II & 11 & 0.43 & 0.36 & & & \\
\hline & \multirow{2}{*}{$2005-2009$} & I & 36 & 0.48 & 0.19 & \multirow{2}{*}{-} & \multirow{2}{*}{60.50} & \multirow{2}{*}{0.0878} \\
\hline & & II & 6 & 0.29 & 0.21 & & & \\
\hline
\end{tabular}

CP: Climber Presence and effect of climbers; I: no climbers in the tree; II: climbers in the tree, causing no damage; III: climbers in the tree, affecting growth; VI: climbers cut and dead. n: number of individuals. Sd: Standard deviation. U: statistical value of MannWhitney. H: statistical value of Kruskal-Wallis. P-value: indicates the level of significance for the tests of Mann-Whitney or KruskalWallis for each assessment period $(\alpha=0.05)$. Climber presence categories with different letters, within each experimental treatment, in each assessment period, are significantly different according to the post-hoc multiple comparisons Dunn test (K independent samples) or with the Mann-Whitney test (two independent samples) - $(\alpha=0.05)$.

The presence of cut and dead climbers on the trees in T6 and T7, observed in figures 1 and 2, is due to the climber cutting performed during the pre-logging forest inventory, considering that in these treatments (T6 and T7) no silvicultural treatment was applied.

Starting from year 2006, the quantity of trees with cut and dead climbers started to decrease in the combined treatments. This reduction is justified by the change of that category of climbers, which essentially migrated to the categories of trees without climbers or with climbers that did not cause damage. That is to say that some trees which were before in the category of cut and dead climbers, were later in the category of trees with climbers. This is evidence that the climber cutting, however effective in the short period of time, has its beneficent effects reduced along time, mainly because of the fast regeneration of climbers in general.

\section{Level of illumination on the tree crowns}

The influence of the solar radiation on the growth of tree species have been studied by various authors in the Brazilian Amazon region (SILVA et al.,1995; SILVA et al., 2001; VIDAL et al.,2002; OLIVEIRA; BRAZ, 2006; COSTA et al., 2007; COSTA et al., 2008). ). The intensity of solar radiation that a tree receives on its crown is a growth limiting factor, because there is a positive effect on tree growth when there is an increased illumination of the crown (BAKER et al., 2003). In this sense, the $\mathrm{PAI}_{\mathrm{DBH}}$ rates of Manilkara huberi and Manilkara paraensis trees were also determined considering two levels of intensity of solar radiation on the trees crowns. The results are presented in table 4. 


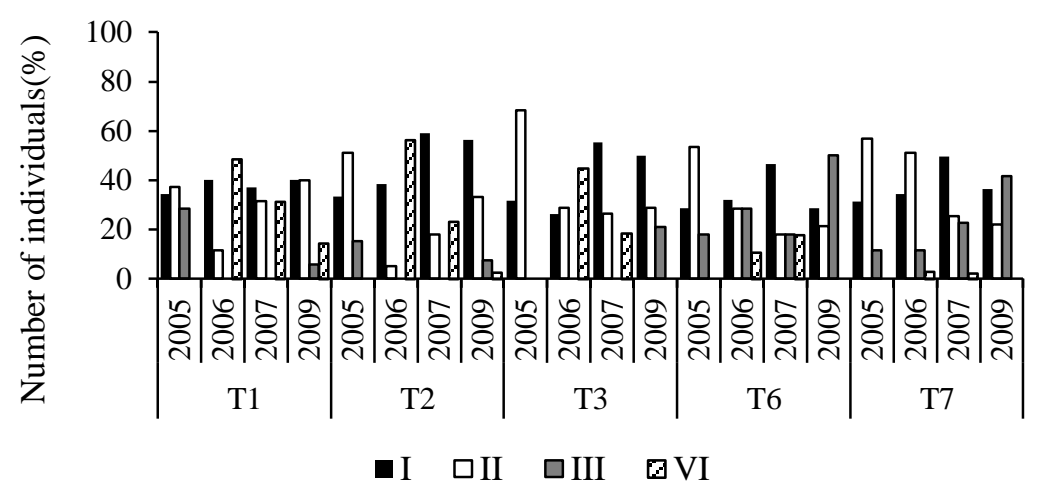

I: no climbers in the tree; II: climbers in the tree, causing no damage; III: climbers in the tree, affecting growth; VI: climbers cut and dead

Figure 1. Changes in the number of Manilkara huberi trees with DBH equal to or greater than $35 \mathrm{~cm}$, according to the presence of climber on the selected trees in a 500 ha sample of a terra firme natural forest, in the municipality of Paragominas, PA.

Figura 1. Mudanças no número de árvores de Manilkara huberi com DAP igual ou maior que $35 \mathrm{~cm}$, em função da presença de cipós nas árvores selecionadas, em 500 ha de uma floresta natural de terra firme, Paragominas, PA.

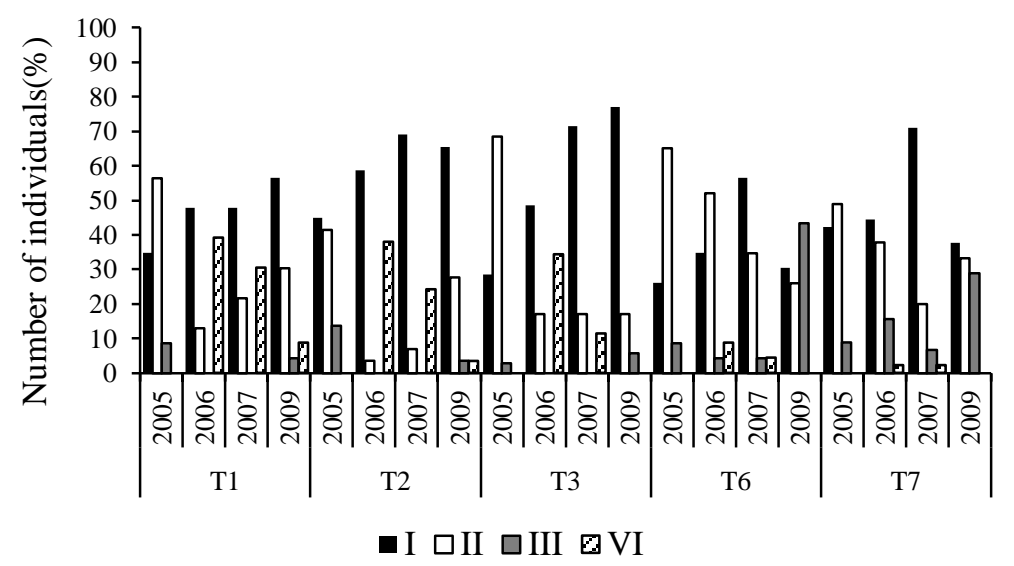

I: no climbers in the tree; II: climbers in the tree, causing no damage; III: climbers in the tree, affecting growth; VI: climbers cut and dead

Figure 2. Changes in the number of Manilkara paraensis trees with DBH equal to or greater than $35 \mathrm{~cm}$, according to the presence of climber on the selected trees in a 500 ha sample of a terra firme natural forest, in the municipality of Paragominas, PA.

Figura 2. Mudanças no número de árvores de Manilkara paraensis com DAP igual ou maior que $35 \mathrm{~cm}$, em função da presença de cipós nas árvores selecionadas, em 500 ha de uma floresta natural de terra firme, Paragominas, PA.

The DBH growth rates of Manilkara huberi individuals with crowns entirely exposed to solar radiation were similar to the ones verified in the individuals with partially illuminated crown, in the four assessed periods. The results of this study are different from that reported by Costa et al. (2007) on Manilkara huberi, where trees whose crown received total illumination had greater diametric increment than the ones which were partially or totally shaded.

In a different way, trees of Manilkara paraensis which received total solar radiation on the crowns showed $\mathrm{PAI}_{\mathrm{DBH}}$ growth rates $45 \%, 22 \%$ and $43 \%$ greater than the partially illuminated individuals, in the 2005-2006, 2007-2009 and 2005-2009 periods. There are studies (SILVA et al., 1995; 
SILVA et al., 2001; VIDAL et al., 2002; OLIVEIRA; BRAZ, 2006; COSTA et al., 2008) reporting similar results as observed for Manilkara paraensis, however for a group of different species.

Table 4. Periodic annual DBH increment $\left(\mathrm{cm}\right.$ year $\left.^{-1}\right)$ of Manilkara huberi trees and Manilkara paraensis trees with DBH greater than or equal to $35 \mathrm{~cm}$, depending on the crown illumination intensity on the selected trees in a 500 ha sample of natural terra firme forest, Paragominas, PA.

Tabela 4. Incremento periódico anual em DAP $\left(\mathrm{cm} \mathrm{ano}^{-1}\right)$ das árvores de Manilkara huberi e Manilkara paraensis com DAP maior ou igual a $35 \mathrm{~cm}$, em função do grau de iluminação das copas das árvores selecionadas, em 500 ha em uma floresta natural de terra firme, Paragominas, PA.

\begin{tabular}{|c|c|c|c|c|c|c|c|}
\hline Species & Period & IL & n & PAI $_{\text {DBH }}$ & Sd & $\mathbf{U}$ & P-value \\
\hline \multirow{8}{*}{$\begin{array}{l}\text { Manilkara } \\
\text { huberi }\end{array}$} & \multirow{2}{*}{ 2005-2006 } & $\mathrm{I}$ & 194 & 0.54 & 0.46 & \multirow{2}{*}{$2,596.50$} & \multirow{2}{*}{0.9424} \\
\hline & & II & 27 & 0.51 & 0.36 & & \\
\hline & \multirow{2}{*}{$2006-2007$} & I & 212 & 0.41 & 0.28 & \multirow{2}{*}{$2,242.50$} & \multirow{2}{*}{0.7671} \\
\hline & & II & 22 & 0.40 & 0.26 & & \\
\hline & \multirow{2}{*}{ 2007-2009 } & I & 171 & 0.61 & 0.37 & \multirow{2}{*}{$1,833.00$} & \multirow{2}{*}{0.5975} \\
\hline & & II & 23 & 0.55 & 0.26 & & \\
\hline & \multirow{2}{*}{ 2005-2009 } & I & 134 & 0.52 & 0.24 & \multirow{2}{*}{833.00} & \multirow{2}{*}{0.7954} \\
\hline & & II & 13 & 0.49 & 0.16 & & \\
\hline \multirow{8}{*}{$\begin{array}{l}\text { Manilkara } \\
\text { paraensis }\end{array}$} & \multirow{2}{*}{ 2005-2006 } & I & 78 & 0.44 & 0.40 & \multirow{2}{*}{662.00} & \multirow{2}{*}{0.0500} \\
\hline & & II & 23 & 0.24 & 0.27 & & \\
\hline & \multirow{2}{*}{ 2006-2007 } & I & 82 & 0.31 & 0.26 & \multirow{2}{*}{$1,173.50$} & \multirow{2}{*}{0.1811} \\
\hline & & II & 34 & 0.26 & 0.24 & & \\
\hline & \multirow{2}{*}{ 2007-2009 } & I & 73 & 0.59 & 0.34 & \multirow{2}{*}{$1,327.00$} & \multirow{2}{*}{0.0500} \\
\hline & & II & 46 & 0.46 & 0.26 & & \\
\hline & \multirow{2}{*}{ 2005-2009 } & I & 53 & 0.46 & 0.20 & \multirow{2}{*}{134.00} & \multirow{2}{*}{0.0007} \\
\hline & & II & 13 & 0.26 & 0.15 & & \\
\hline
\end{tabular}

IL: level of crown illumination; I: crown entirely exposed to light; II: partially illuminated crown. n: number of individuals. Sd: Standard deviation. U: statistical value of Mann-Whitney. P-value: indicates the level of significance in the test of Mann-Whitney for each assessment period $(\alpha=0.05)$

Some tree species do not depend on the direct solar radiation to develop, but they would benefit from the canopy openings through gaps, both natural and generated by forest logging (JARDIM; SOARES, 2010). This can happen with Manilkara paraensis, which although is considered a shadetolerant species, showed positive reactions to increased illumination on the crowns of its trees. Silva et al. (2001) point out that this kind of information has important implications to silviculture, because it justify the application of thinning to free the crowns of trees which are suitable for next logging. In this way the growth rates of trees in the tropical forests would be increased, contributing to the reduction of time between cutting cycles.

Figures 3 and 4 show the variation in the number of Manilkara huberi and manilkara paraensis selected trees in each treatment, according to the intensity level of solar radiation on their crowns observed in the four measurements.

Manilkara huberi showed, in the combined treatments, from 2005 to 2006, increases from approximately $5.26 \%$ to $22.2 \%$ in the number of trees with completely exposed crowns. T6 showed an increase of $60 \%$ and $\mathrm{T} 7$ maintained the quantity of completely exposed individuals stable in the same period. Manilkara paraensis showed increases from 5.88\% to $63.64 \%$ in the combined treatments from 2005 to 2006, however showed reduction of $10 \%$ in T7 and maintained the same quantity of individuals with completely exposed crowns in T6.

Considering the entire period (2005 to 2009), Manilkara huberi showed increases from $7.41 \%$ to $10.53 \%$ of individuals with completely exposed crowns in the combined treatments. T6 showed the greatest increase $(33.33 \%)$ and the unlogged forest showed a reduction of approximately $7 \%$ in the number of individuals with crowns completely exposed to solar radiation. Manilkara paraensis showed a reduction in the quantity of completely exposed trees, in the period 2005-2009, in the treatments T3 (23.07\%), T6 (21.43\%) and T7 (30\%). The treatments $\mathrm{T} 1$ and $\mathrm{T} 2$ showed respectively increases of approximately $18.18 \%$ and $11.76 \%$. 


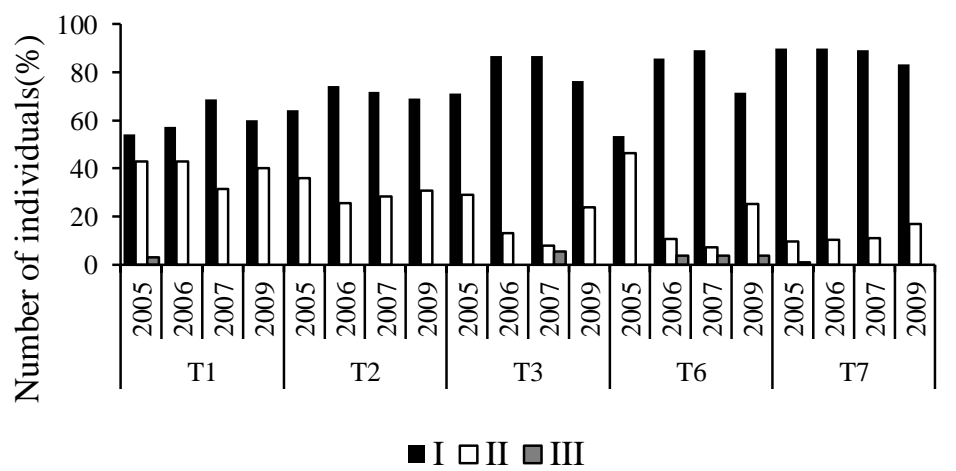

I: completely exposed crown; II: partially exposed crown; III: completely shaded crown by nearby trees.

Figure 3. Changes in the number of Manilkara huberi trees with DBH equal to or greater than $35 \mathrm{~cm}$, depending on the crown illumination intensity on the PCTs in a 500 ha sample of a terra firme natural forest, in the municipality of Paragominas, PA.

Figura 3. Mudanças ocorridas no número de árvores de Manilkara huberi com DAP igual ou maior que $35 \mathrm{~cm}$, em função do grau de iluminação das copas das árvores selecionadas, em 500 ha de uma floresta natural de terra firme, Paragominas, PA.

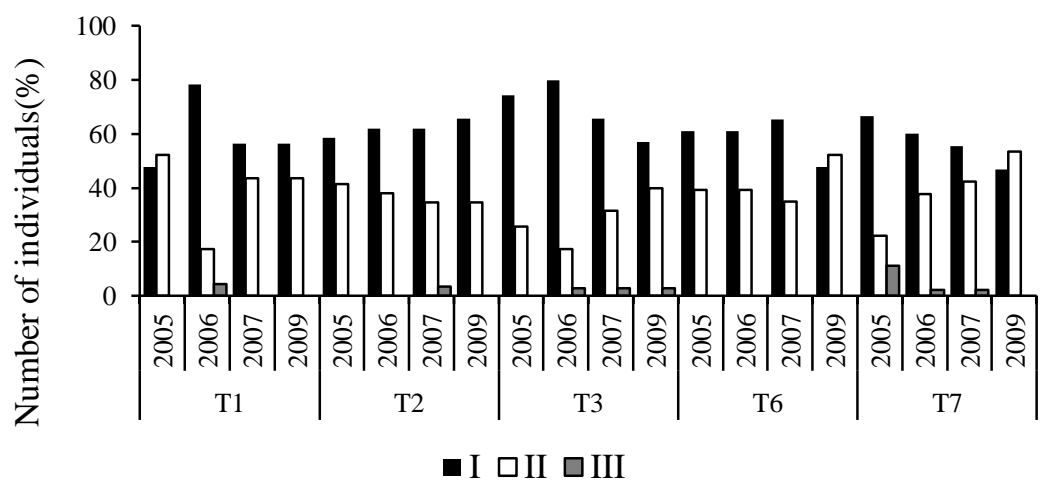

I: copa completamente exposta à luz; II: copa parcialmente iluminada; III: copa completamente coberta por copas de árvores vizinhas. I: completely exposed crown; II: partially exposed crown; III: completely shaded crown by nearby trees.

Figure 4. Changes in the number of Manilkara paraensis with DBH equal to or greater than $35 \mathrm{~cm}$, depending on the crown illumination intensity on the PCTs in a 500 ha sample of a terra firme natural forest, in the municipality of Paragominas, PA.

Figura 4. Mudanças no número de árvores de Manilkara paraensis com DAP igual ou maior que $35 \mathrm{~cm}$, em função do grau de iluminação das copas das árvores selecionadas, em 500 ha de uma floresta natural de terra firme, Paragominas, PA.

The silvicultural interventions, for instance the timber logging and/or the climber cutting, contributed to the appearance of trees with crowns completely exposed to light. This is supported by the observation that, in the 2005-2006 and 2005-2009 periods, Manilkara huberi and Manilkara paraensis trees did not show increases on number of trees with crowns completely exposed to light in the unlogged forest.

\section{CONCLUSION}

- Manilkara huberi and Manilkara paraensis showed positive reactions, in terms of diameter growth, to the post-logging silviculture applied after logging in the area. However, considering the differences on increments of trees between the evaluated periods, it is possible to say that the short period of time elapsed since the application of the silvicultural treatments (four years), still does not allow to make accurate statements about the most adequate treatment system to be applied for the two species. 


\section{REFERENCES}

BAKER, T. R.; SWAINE, M. D.; BURSLEM, D. F. R. P. Variation in tropical forest growth rates: combined effects of functional group composition and resource availability. Perspectives in Plant Ecology, Evolution and Systematics, v. 6, p. 21 - 36, 2003.

CARVALHO, J. O. P. de; SILVA, J. N. M.; LOPES, J. do C. A. Growth rate of a terra firme rain forest in brazilian amazonia over an eight-year period in response to logging. Acta Amazônica, Manaus, v. 34(2), p. 209 - 217, 2004.

COSTA, D. H. M.; CARVALHO, J. O. P. de; BERG, E. V. D. Crescimento diamétrico de maçaranduba (Manilkara huberi Chevalier) após a colheita de madeira. Amazônia Ciência e Desenvolvimento, Belém, v. 3, n. 5, p. 65 - 76, 2007.

COSTA, D. H. M.; SILVA, J. N. M.; CARVALHO, J. O. P. de. Crescimento de árvores em uma área de terra firme na Floresta Nacional do Tapajós após a colheita de madeira. Revista de Ciências Agrárias, Belém, n. 50, p. 63 - 762008.

JARDIM, F. C. da S.; SOARES, M. da S. Comportamento de Sterculia pruriens (Aubl.) Schum. em floresta tropical manejada em Moju-PA. Acta Amazônica. v. 40 (3), p. 535 - 542, 2010.

MACIEL, M. de N.; BASTOS, P. C. de O; CARVALHO, J. O. P.; WATRIN, O. dos S. Uso de imagens orbitais na estimativa de parâmetros estruturais de uma floresta primária no município de Paragominas, Estado do Pará. Revista de Ciências Agrárias, Belém, n. 52, p. 159 - 178, 2009.

OLIVEIRA, M. V. N. d'; BRAZ, E. M. Estudo da dinâmica da floresta manejada no projeto de manejo florestal comunitário do PC Pedro Peixoto na Amazônia Ocidental. Acta Amazônica. v. 36 (2), p. 177 $182,2006$.

PEÑA-ClAROS, M.; PETERS, E. M.; JUSTINIANO, M. J.; BONGERS, F.; BLATE, G. M.; FREDERICKSEN, T. S.; PUTZ, F. E. Regeneration of commercial tree species following silvicultural treatments in a moist tropical forest. Forest Ecology and Management. v. 255, p. 1283 - 1293, 2008.

PÉREZ-SALICRUP, D. R.; CLAROS, A.; GÚZMAN, R.; LICONA, J. C.; LED EZMA, F.; PINARD, M. A.; PUTZ, F. E. Cost and efficiency of cutting lianas in a lowland liana forest of Bolivia. Biotropica, v. 33 (2) p. 324 - 3292001.

PINHEIRO, K. A. O.; CARVALHO, J. O. P. de; QUANZ, B.; FRANCEZ, L. M. de B.; SCHWARTZ, G. Fitossociologia de uma área de preservação permanente no leste da Amazônia: indicação de espécies para recuperação de áreas alteradas. Floresta, Curitiba, v. 37, n. 2, p. 175 - 187, 2007.

RODRIGUES, T. E.; SILVA, R. das C.; SILVA, J. M. L. da; GAMA, J. R. N. F.; VALENTE, M. A.; OLIVEIRA JÚNIOR, R. C. de. Caracterização e classificação dos solos do município de Paragominas, Estado do Pará. Belém: Embrapa Amazônia Oriental, (Embrapa Amazônia Oriental. Documentos, 162), 2003. $51 \mathrm{p}$.

SANDEL, M. P.; CARVALHO, J. O. P. de. Anelagem de Árvores como tratamento silvicultural em florestas naturais da Amazônia brasileira. Revista de Ciências Agrárias, Belém, n. 33, p. 9 - 32, 2000.

SILVA, J. N. M.; CARVALHO, J. O. P.; LOPES, J. DO C. A.; ALMEIDA, B. F. DE; COSTA, D. H. M.; OLIVEIRA, L. C. DE; VANCLAY, J. K.; SKOVSGAARD, J. P. Growth and yield of a tropical rain forest in the Brazilian Amazon 13 years after logging. Forest Ecology and Management, n. 71, p. 267 $274,1995$.

SILVA, J. N. M; SILVA, S. M. A. da; COSTA, D. H. M.; BAIMA, A. M. V.; OLIVEIRA, L. C. de; CARVALHO, J. O. P. de; LOPES, J. do C. A. Crescimento, mortalidade e recrutamento em florestas de terra firme da Amazônia Oriental: observações nas regiões do Tapajós e Jarí. In: SILVA, J. N. M.; CARVALHO, J. O. P. de; YARED, J. A. G. (Ed.) A silvicultura na Amazônia Oriental: contribuições do projeto Embrapa/DFID. Belém: Embrapa Amazônia Oriental/DFID, 2001. p. 291 - 308. 
SILVA, J. N. M. Manejo Florestal. 3. ed. Brasília: Embrapa Informação Tecnológica, 2001. v. 1. 49 p.

SILVA, R. P. da; NAKAMURA, S.; AZEVEDO, C. P. de; CHAMBERS, J. ROCHA, R. de M.; PINTO, A. C. M.; SANTOS, J. dos; HIGUCHI, N. Uso de banda dendrométrica na definição de padrões de crescimento individual em diâmetro de árvores da bacia do rio cuieiras. Acta Amazônica, v. 33 (1), p. 67 - 84, 2003.

SILVA, J. N. M.; LOPES, J. C. A.; OLIVEIRA, L. C. de; SILVA, S. M. A. da; CARVALHO, J. O. P.; COSTA, D. H. M.; MELO, M. S.; TAVARES, M. J. M. Diretrizes para instalação e medição de parcelas permanentes em florestas naturais da Amazônia brasileira. 1. ed. Belém: Embrapa, 2005. 68 p.

VELOSO, H. P.; RANGEL FILHO, A. L. R.; LIMA, J. C. A. Classificação da vegetação brasileira adaptada a um sistema universal. IBGE, Departamento de recursos naturais e estudos ambientais, Rio de Janeiro. 1991. 124 p.

VIDAL, E; VIANA, V. M.; BATISTA, J. L. F. Crescimento de floresta tropical três anos após colheita de madeira com e sem manejo florestal na Amazônia oriental. Scientia Forestalis. n. 61, p. 133 - 143, 2002.

VILLEGAS, Z.; PEÑA-ClAROS, M.; MOSTACEDO, B.; ALARCÓN, A.; LICONA, J. C.; LEAÑO, C.; PARIONA, W.; CHOQUE, U. Silvicultural treatments enhance growth rates of future crop trees in a tropical dry forest. Forest Ecology and Management, v. 258, p. 971 - 977, 2009.

WADSWORTH, F. H. Producción forestal para América Tropical. Washington: USDA, 2000. 602 p.

WADSWORTH, F. H.; ZWEEDE, J. C. Liberation: acceptable production of tropical forest timber. Forest Ecology and Management, v. 233 (1), p. 45 - 51, 2006.

WATRIN, O. dos S.; ROCHA, A. M. A. Levantamento da vegetação natural e do uso da terra no município de Paragominas (PA) utilizando imagens TM/LANDSAT. Belém: Embrapa-CPATU. Embrapa-CPATU. Boletim de Pesquisa, 124, 1992. 40 p. 
